\title{
The Function of Vitamin $B_{12}$ in the Metabolism of Propionate by the Protozoan Ochromonas malhamensis
}

\author{
By H. R. V. ARNSTEIN AND A. M. WHITE \\ National Institute for Medical Research, Mill Hill, London, N.W. 7
}

(Received 7 November 1961)

The flagellate protozoan Ochromonasmalhamensis has a growth requirement for vitamin $B_{12}$ (cobalamin), which resembles that of animals in its specificity (Coates \& Ford, 1955). In particular, neither deoxyribosides nor methionine, which support the growth of lactobacilli and vitamin $B_{12}$ requiring mutants of Escherichia coli respectively, can replace vitamin $B_{12}$ (Hutner, Provasoli \& Filfus, 1953; Johnson, Holdsworth, Porter \& Kon, 1957 ; A. M. White, unpublished results). As in animals, pseudovitamin $B_{12}$ (adenylcobamide) and several other related analogues are also inactive (Coates \& Ford, 1955; Coates \& Kon, 1957). Since vitamin $\mathrm{B}_{12}$-deficient cells of $O$. malhamensis may be readily obtained by growing cultures in the presence of suboptimum concentrations of the vitamin, this organism appeared to be particularly suitable for experiments designed to elucidate ultimately the function of vitamin $B_{12}$ in mammalian metabolism.

In the present work, early metabolic changes after the addition of vitamin $B_{12}$ to suspensions of deficient cells were investigated on the assumption that any metabolic reaction requiring vitamin $B_{12}$ as a coenzyme would be stimulated either earlier or to a greater extent than reactions affected only indirectly by lack of the vitamin.

The results of this work have been reported in two communications to the Biochemical Society (White \& Arnstein, 1960; Arnstein \& White, $1961 a)$.

\section{EXPERIMENTAL}

Growth of cells. The stock culture of Ochromonas malhamensis, var. Pringsheim, was obtained from Dr J. E. Ford, National Institute for Research in Dairying, Shinfield, Berks. It was maintained by weekly transfers to fresh growth medium (10 ml.) containing $0.2-0.4 \mu \mathrm{mg}$. of cyanocobalamin $/ \mathrm{ml}$. in $100 \mathrm{ml}$. conical flasks. Incubation was at $24^{\circ}$ in light. Cells from 7 -day-old stock cultures were isolated by centrifuging at $500 \mathrm{~g}$ for $5 \mathrm{~min}$., and resuspended in an equal volume of $0.9 \% \mathrm{NaCl}$ or water. Flat bottles $(12 \mathrm{~cm} . \times 21 \mathrm{~cm} . \times 5 \mathrm{~cm}$. or $19 \mathrm{~cm} . \times 22 \mathrm{~cm} . \times$ $6 \mathrm{~cm}$.) containing $150 \mathrm{ml}$. or $600 \mathrm{ml}$. respectively of growth medium (Ford, 1953) with limiting amounts of cyanocobalamin $(0.02-0.04 \mu \mathrm{mg} . / \mathrm{ml}$.) were inoculated with this suspension $(3-5 \%, v / v)$. In one experiment cell counts showed that the stock culture contained $4.5 \times 10^{6}$ cells $/ \mathrm{ml}$. and a $5 \%$ inoculum would thus give approx. $0.2 \times 10^{6}$ cells/ml. of growth medium at the beginning of the incubation. The bottles were incubated at $30^{\circ}$ in the dark with shaking (cf. Ford, 1953) for about $70 \mathrm{hr}$. With $0.02 \mu \mathrm{mg}$. of cyanocobalamin $/ \mathrm{ml}$., the final cell count was $5 \times 10^{6}$ cells/ $\mathrm{ml}$. Usually, however, growth was followed by measuring the extinction at $580 \mathrm{~m} \mu$ of a culture that had been diluted with an equal volume of water and heated at $100^{\circ}$ for about $15 \mathrm{~min}$. With a Uvispek $\mathrm{H} 700$ spectrophotometer (Hilger and Watts Ltd., London) and extinction of 1 corresponded to $12 \times 10^{6} \mathrm{cells} / \mathrm{ml}$.

Cells were harvested by centrifuging at $500 \mathrm{~g}$ for $5 \mathrm{~min}$., washed by resuspension in water or growth medium and centrifuged again in the same way. Finally, the cells were resuspended in either water or growth medium, as required.

Oxidation experiments. Oxidation of ${ }^{14} \mathrm{C}$-labelled compounds by cell suspensions was usually carried out in Warburg flasks closed with rubber stoppers. Each flask contained the labelled substrate in water or growth medium $\left(2 \mathrm{ml}\right.$.) and approx. $500 \times 10^{6}$ cells. The centre well was filled with a solution of $\mathrm{NaHCO}_{3}(0.25 \mathrm{~m}$-mole) in $20 \%$ $\mathrm{NaOH}(0.3 \mathrm{ml}$.) and the side arm with $10 \%(\mathrm{w} / \mathrm{v})$ trichloroacetic acid $(0.5 \mathrm{ml}$.). In the experiments with labelled glucose, the side arms contained $0.25 \mathrm{M}$-glucose in $10 \%$ trich]oroacetic acid (0.5 ml.). After incubation at $30^{\circ}$ with shaking, the flasks were cooled in ice and the acid was tipped from the side arm. Control flasks were kept cooled in ice. After $18 \mathrm{hr}$, the contents of the centre well were added to saturated aq. $\mathrm{Ba}(\mathrm{OH})_{2}\left(5 \mathrm{ml}\right.$.), $\mathrm{BaCO}_{3}$ was centrifuged, washed twice with water, ethanol, ether and dried before assaying for ${ }^{14} \mathrm{C}$.

In the experiment on the oxidation of propionate by growing cultures, $\mathrm{CO}_{2}$ was collected in $20 \%(\mathrm{w} / \mathrm{v}) \mathrm{NaOH}$ $\left(1.0 \mathrm{ml}\right.$. containing $20 \mathrm{mg}$. of $\mathrm{NaHCO}_{3}$ ) in adaptors which were attached to the small flat bottles, $10 \%$ trichloroacetic acid $(10 \mathrm{ml}$.) being injected into the medium at the end of the incubation period. Cells were isolated by centrifuging (500g for $5 \mathrm{~min}$.).

Extraction of cells. In the experiments with labelled glucose, the cells were extracted once with $0.25 \mathrm{M}$-glucose in $5 \%(w / v)$ trichloroacetic acid $\left(5 \mathrm{ml}\right.$.) at $0^{\circ}$, and defatted with portions (approx. $5 \mathrm{ml}$.) of boiling ethanol, ethanolether $(3: 1, v / v)$ and ether. After drying, the material was assayed for ${ }^{14} \mathrm{C}$. This fraction is referred to below as 'extracted cells'.

Isolation of protein. After incubation the flasks were cooled to $0^{\circ}$ and the cells were isolated by centrifuging (500 $\mathrm{g}$ for $5 \mathrm{~min}$.). The cells were extracted twice with $5 \%$ trichloroacetic acid at $90^{\circ}$ for 15 min., boiling ethanol, boiling ethanol-ether $(3: 1, v / v)$ and boiling ether. After drying, the samples were assayed for ${ }^{14} \mathrm{C}$.

Isolation of methylmalonic acid and succinic acid after 
incubation of cells with sodium $\left[2-{ }^{14} \mathrm{C}\right]$ propionate. Sufficient cells were suspended in water or growth medium to give a concentration of approx. $2.6 \times 10^{8} \mathrm{cells} / \mathrm{ml}$. After incubation with the labelled sodium propionate, samples $(2 \mathrm{ml}$.) were removed for the isolation of protein. The remaining cells after centrifuging at $0^{\circ}$ were washed twice with ice-cold sodium propionate solution $(0.9 \%)$. They were then kept for $1 \mathrm{hr}$. in the presence of $0.01 \mathrm{~N}-\mathrm{NaOH}$ $(8 \mathrm{ml}$.). The broken cells were acidified by the addition of $6 \mathrm{~N}-\mathrm{HCl}(0.1 \mathrm{ml}$.$) . Carrier succinic acid (10 \mu \mathrm{moles})$ and methylmalonic acid ( $10 \mu$ moles) were added and the slurry was freeze-dried. The freeze-dried solid was mixed with $0.5 \mathrm{~N}-\mathrm{H}_{2} \mathrm{SO}_{4}(0.5 \mathrm{ml}$.) and Celite $(1 \mathrm{~g}$.$) . The mixture was$ packed into a column with ether which had been previously equilibrated with $0.5 \mathrm{~N}-\mathrm{H}_{2} \mathrm{SO}_{4}$, and the column was eluted with acid-equilibrated ether $(200 \mathrm{ml}$.). After reducing the volume of the eluate to $20 \mathrm{ml}$. the crude mixture of acids was extracted into a slight excess of $0.01 \mathrm{~N}-\mathrm{NaOH}$. The slightly alkaline solution was evaporated to dryness, and methylmalonic acid and succinic acid were isolated from the residue by using a Celite column (7.5 g.) according to the method of Swim \& Krampitz (1954). The isolated methylmalonic acid was rechromatographed to constant specific radioactivity. For succinic acid, attainment of constant radioactivity was facilitated by treatment with $\mathrm{KMnO}_{4}$. The fractions containing the crude acid from the primary separation were evaporated to dryness and treated for $30 \mathrm{~min}$. under reflux with $0.4 \mathrm{ml}$. of a solution of $\mathrm{KMnO}_{4}(0 \cdot 05 \%)$. Two drops of ethanol were then added and the $\mathrm{MnO}_{2}$ was separated by centrifuging. The supernatant was rechromatographed until succinic acid of constant specific radioactivity was obtained.

Radioactivity determinations. Barium carbonate and protein were counted as samples of infinite thickness on disks of $1 \mathrm{~cm} .^{2}$ or $0.3 \mathrm{~cm} .{ }^{2}$ area, a thin end-window Geiger-

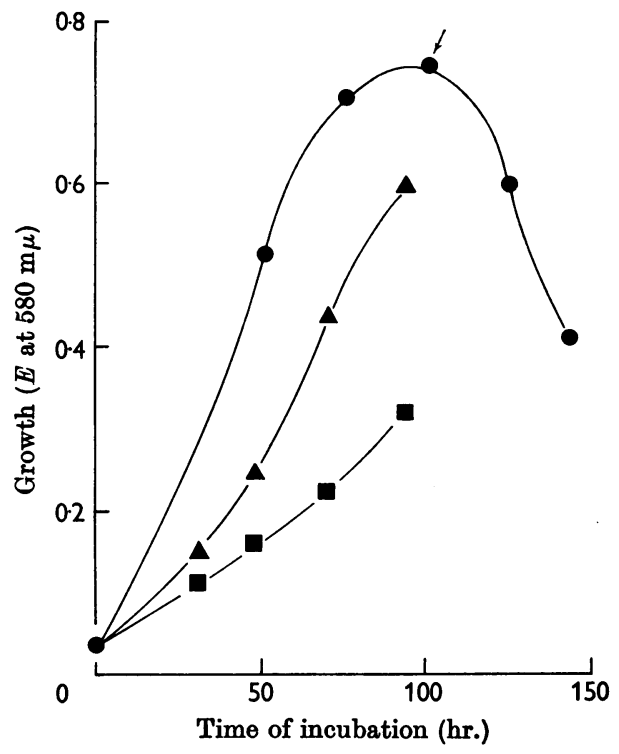

Fig. 1. Growth of Ochromonas malhamensis with different concentrations of cyanocobalamin: $100 \mu \mu \mathrm{g} . / \mathrm{ml}$. (O), $50 \mu \mu \mathrm{g} . / \mathrm{ml}$. (A) and $10 \mu \mu \mathrm{g} . / \mathrm{ml}$. ( $\mathbf{(})$. The arrow indicates commencement of cell lysis.
Müller counter (Popják, 1950) being used. The absolute specific radioactivity was calculated from the counting rate of a reference standard of poly $\left(\left[{ }^{14} \mathrm{C}\right]\right.$ methyl methacrylate) (specific radioactivity $1 \mu \mathrm{c} / \mathrm{g}$.; The Radiochemical Centre, Amersham, Bucks.). Succinate and methylmalonate were counted as the sodium salts on lens tissue $\left(2 \mathrm{~cm} .{ }^{2}\right)$ mounted on polythene disks, the amount of acids being determined by titration. When the weight of material plated was less than $1 \mathrm{mg}$. the counting rate was proportional to the amount. The efficiency of the counter under these conditions was approx. $8 \%$.

Materials. All labelled compounds were obtained from The Radiochemical Centre. The abbreviation U-14C refers to uniformly labelled compounds.

Cyanocobalamin was purchased from Glaxo Laboratories Ltd., Greenford, Middx. The methylamide and anilide analogues of cyanocobalamin were gifts of Dr E. Lester Smith, F.R.S. (Glaxo Laboratories Ltd.). The methylamide contained less than $0.01 \%$ and the anilide approx. $0.05 \%$ of cyanocobalamin as determined by paper chromatography and microbiological assay (E. Lester Smith, personal communication). The other vitamin $B_{12}$ analogues were obtained from Dr J. E. Ford (National Institute for Research in Dairying).

Celite was the product of Johns-Manville, Lompoc, Calif., U.S.A. and was grade no. $\mathbf{5 3 5}$.

\section{RESULTS}

Effect of vitamin $B_{12}$ on the growth of Ochromonas malhamensis. Under our conditions, $10 \mu \mu \mathrm{g}$. of cyanocobalamin $/ \mathrm{ml}$. gave reasonable growth, which was, however, much less than with $100 \mu \mu \mathrm{g} . / \mathrm{ml}$. (Fig. 1). Since deficient cells were required for the experiments, cells were always grown with suboptimum concentrations $(10-30 \mu \mu \mathrm{g} . / \mathrm{ml}$.$) , but$ were harvested at about $70 \mathrm{hr}$., before growth had completely ceased. In preliminary experiments, the metabolism of older cells (96 hr. incubation) was much reduced.

In further trial experiments, addition of excess of cyanocobalamin $(20 \mu \mathrm{mg} . / \mathrm{ml}$.) to a culture that had virtually ceased to grow after incubation for $123 \mathrm{hr}$. in deficient medium resulted in an observable resumption of growth within $3 \mathrm{hr}$. (measured by the increase in extinction at $580 \mathrm{~m} \mu$ after steaming). It was concluded therefore that any metabolic changes responsible for the stimulation of growth by vitamin $B_{12}$ must take place within this time.

Metabolism of glucose. The results given in Table 1 show that vitamin $B_{12}$ had no effect on the ability of cells to oxidize glucose to $\mathrm{CO}_{2}$. The conversion of glucose into the extracted cell fraction was, however, stimulated by approx. $50 \%$ when vitamin $B_{12}$ was added.

Oxidation of formate, acetate and propionate. The oxidation of formate was decreased by about $50 \%$ by addition of vitamin $B_{12}$. Acetate oxidation was slightly increased, but the oxidation of propionate 
Table 1. Metabolism of glucose by cell suspension of Ochromonas malhamensis

Each Warburg flask contained $2.4 \times 10^{8}$ cells in growth medium $(2 \mathrm{ml}$.) with [14C]glucose (0.5 mg.). Cyanocobalamin ( $1 \mu \mathrm{g}$;) was added where shown. Incubation was for $1 \mathrm{hr}$. at $30^{\circ}$; control flasks were kept at $0^{\circ}$. + , Present; -, absent.

\begin{tabular}{|c|c|c|c|c|}
\hline \multirow{2}{*}{$\begin{array}{l}\text { Labelled } \\
\text { substrate }\end{array}$} & \multirow{2}{*}{$\begin{array}{c}\text { Radioactivity } \\
(\mu \mathrm{C})\end{array}$} & \multirow[b]{2}{*}{ Vitamin $\mathbf{B}_{12}$} & \multicolumn{2}{|c|}{$(\mu \mathrm{mc} / \mathrm{g})}$. \\
\hline & & & $\mathrm{BaCO}_{3}$ & Extracted \\
\hline $\begin{array}{l}{[1-14 \mathrm{C}] \text { Glucose }} \\
{[1-14 \mathrm{C}] \text { Glucose }} \\
{\left[6-{ }^{14} \mathrm{C}\right] \text { Glucose }} \\
{[6-14 \mathrm{C}] \text { Glucose }} \\
{[\mathrm{U}-14 \mathrm{C}] \text { Glucose }} \\
{\left[\mathrm{U}-{ }^{14} \mathrm{C}\right] \text { Glucose }}\end{array}$ & $\begin{array}{l}1 \cdot 23 \\
1 \cdot 23 \\
0 \cdot 60 \\
0 \cdot 60 \\
1 \cdot 41 \\
1 \cdot 41\end{array}$ & $\begin{array}{l}+ \\
+ \\
+ \\
+ \\
-\end{array}$ & $\begin{array}{r}738 \\
761 \\
1031 \\
1031 \\
960 \\
951\end{array}$ & $\begin{array}{l}3438 \\
2318 \\
4380 \\
3068 \\
2709 \\
1945\end{array}$ \\
\hline & \multicolumn{4}{|c|}{ Control flasks } \\
\hline $\begin{array}{l}{\left[1{ }^{14} \mathrm{C}\right] \text { Glucose }} \\
{\left[6-{ }^{14} \mathrm{C}\right] \text { Glucose }} \\
{\left[\mathrm{U}-{ }^{14} \mathrm{C}\right] \text { Glucose }}\end{array}$ & $\begin{array}{l}1.23 \\
0.60 \\
1 \cdot 41\end{array}$ & $\begin{array}{l}+ \\
+ \\
+\end{array}$ & $\begin{array}{l}2 \cdot 9 \\
0 \cdot 9 \\
3 \cdot 9\end{array}$ & $\begin{array}{r}7 \cdot 7 \\
15 \cdot 6 \\
50 \cdot 6\end{array}$ \\
\hline
\end{tabular}

Table 2. Oxidation of formate, acetate and propionate

Each Warburg flask contained 3.0 $\times 10^{8}$ cells in either growth medium or water $(2 \mathrm{ml}$.) and the following substrates: sodium [ ${ }^{14} \mathrm{C}$ ] formate $(1 \mu \mathrm{C}, 0 \cdot 165 \mu \mathrm{mole})$, sodium [2-14 C]acetate $(1 \mu \mathrm{C}, 1 \mu \mathrm{mole})$ or sodium [2-14 $\mathrm{C}$ ]propionate $(1.1 \mu \mathrm{c}, 0.44 \mu \mathrm{mole})$. Cyanocobalamin $\left(1 \mu \mathrm{g}\right.$.) was present where indicated. Incubation was at $30^{\circ}$ for $1 \mathrm{hr}$; ; control flasks were kept at $0^{\circ}$. Results of Expt. no. 2 are mean values of duplicates which differed by less than $10 \%$. +, Present; - , absent.

$\begin{aligned} \text { Expt. } & \begin{array}{c}\text { Labelled } \\ \text { substrate }\end{array} \\ 1 & \text { Formate } \\ 1 & \text { Formate } \\ 2 & \text { Formate } \\ 2 & \text { Formate } \\ 2 & \text { Acetate } \\ 2 & \text { Acetate } \\ 2 & \text { Propionate } \\ 2 & \text { Propionate } \\ 2 & \text { Propionate } \\ 2 & \text { Propionate } \\ & \\ 1 & \text { Formate } \\ 2 & \text { Formate } \\ 2 & \text { Acetate } \\ 2 & \text { Propionate } \\ 2 & \text { Propionate }\end{aligned}$

\begin{tabular}{|c|c|c|c|}
\hline Medium & Vitamin $\mathrm{B}_{12}$ & $\begin{array}{c}\text { Sp. activity } \\
\text { of } \mathrm{BaCO}_{3} \\
(\mu \mathrm{c} / \mathrm{g} .)\end{array}$ & $\begin{array}{l}\text { Amount of } \\
\text { substrate } \\
\text { oxidized } \\
\text { ( } \mu \mathrm{m} \text {-moles) }\end{array}$ \\
\hline Growth medium & + & 0.450 & 3.55 \\
\hline Growth medium & - & 0.684 & 5.5 \\
\hline Water & + & 0.406 & $\mathbf{3} \cdot \mathbf{3}$ \\
\hline Water & - & 0.731 & $6 \cdot 1$ \\
\hline Growth medium & + & $3 \cdot 86$ & 192 \\
\hline Growth medium & - & $3 \cdot 44$ & 161 \\
\hline Growth medium & + & $3 \cdot 86$ & 77 \\
\hline Growth medium & - & 0.060 & $1 \cdot 0$ \\
\hline Water & + & $4 \cdot 835$ & 96 \\
\hline Water & - & 0.108 & $1 \cdot 8$ \\
\hline \multicolumn{4}{|c|}{ Control flasks } \\
\hline Growth medium & + & 0.025 & \\
\hline Water & + & 0.014 & \\
\hline Growth medium & + & 0.017 & \\
\hline Growth medium & + & 0.006 & \\
\hline Water & + & 0.019 & \\
\hline
\end{tabular}

Table 3. Conversion of propionate into methylmalonate and succinate by Ouhromonas malhamensis in the presence of cyanocobalamin or its methylamide analogue

The incubation flasks (250 ml.) contained: $26 \times 10^{8}$ cells in $10 \mathrm{ml}$. of suspension; $4 \mu \mathrm{g}$. of cyanocobalamin or $4 \mu \mathrm{g}$. of the methylamide; sodium [2.14 C]propionate $\left(4 \cdot 5 \mu \mathrm{o}, 1.08 \mu\right.$ moles). Incubation was for $1 \mathrm{hr}$. at $30^{\circ}$.

\begin{tabular}{|c|c|c|c|c|}
\hline \multirow[b]{2}{*}{ Suspension } & \multirow[b]{2}{*}{ Addition } & \multirow{2}{*}{$\begin{array}{l}\text { Sp. activity } \\
\text { of protein } \\
\text { ( } \mu \mathrm{c} / \mathrm{g} .)\end{array}$} & \multicolumn{2}{|c|}{$\begin{array}{l}\text { Total radioactivity }(\mu \mathrm{mc}) \\
\text { in dicarboxylic acids }\end{array}$} \\
\hline & & & Mothylmalonic & Succinic \\
\hline Water & $\begin{array}{l}\text { None } \\
\text { Cyanocobalamin } \\
\text { Methylamide } \\
\text { Cyanocobalamin* }\end{array}$ & $\begin{array}{l}0 \cdot 10 \\
7 \cdot 10 \\
1 \cdot 05 \\
0 \cdot 06\end{array}$ & $\begin{array}{l}1 \cdot 84 \\
0 \cdot 31 \\
1 \cdot 59 \\
-\end{array}$ & $\begin{array}{l}0.03 \\
1.36 \\
0.40 \\
-\end{array}$ \\
\hline Medium & $\begin{array}{l}\text { None } \\
\text { Cyanocobalamin } \\
\text { Methylamide } \\
\text { Cyanocobalamin* }\end{array}$ & $\begin{array}{l}0 \cdot 128 \\
8 \cdot 36 \\
1 \cdot 78 \\
0 \cdot 04\end{array}$ & $\begin{array}{l}3 \cdot 44 \\
0 \cdot 40 \\
0 \cdot 77 \\
-\end{array}$ & $\begin{array}{c}0.03 \\
1.67 \\
0.99 \\
-\end{array}$ \\
\hline
\end{tabular}

* Control flasks kept at $0^{\circ}$. 
was stimulated to a far greater extent than that of any other substrate (Table 2). Moreover, in the absence of vitamin $B_{12}$ there was an almost complete block in propionate oxidation. This is also illustrated in Fig. 2, which shows further that the marked increase in the ability of deficient cells to oxidize propionate takes place already after incubation for $15 \mathrm{~min}$. in the presence of cyanocobalamin. Table 3 demonstrates that in this organism the metabolism of propionate involves the formation of methylmalonate and succinate and that vitamin $B_{12}$-deficient cells are unable to convert methylmalonate into succinate.

A comparison of the effect of low concentrations $(0.01 \mu \mathrm{g} . / \mathrm{ml}$.) of cyanocobalamin and the coenzyme

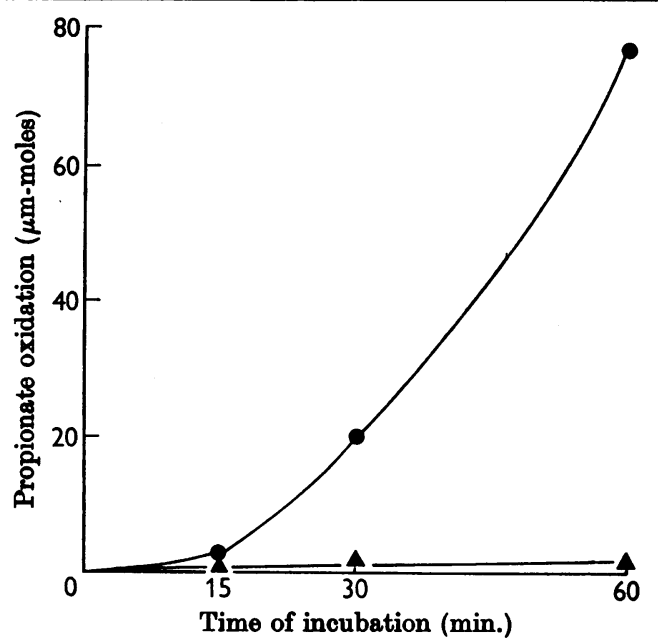

Fig. 2. Stimulation of propionate oxidation by Ochromonas malhamensis after addition of cyanocobalamin. Each flask contained $6 \times 10^{8}$ cells in $2 \mathrm{ml}$. of growth medium. $\Delta$, Deficient cells; 9 , deficient cells + cyanocobalamin (1 $\mu \mathrm{g}$.). form of cobalamin (Weissbach, Toohey \& Barker, 1959) shows that the latter was almost twice as active (Table 4). In another experiment (Fig. 3) it was found that the coenzyme form was more quickly as well as more efficiently utilized. When the methylamide and anilide analogues, which inhibit the effect of vitamin $B_{12}$ on the growth of this organism (Ford, 1959), were examined for activity, only the anilide inhibited the effect of either cyanocobalamin or the coenzyme on propionate oxidation, whereas the methylamide increased propionate oxidation markedly (Table 4). Moreover, the methylamide analogue was active at

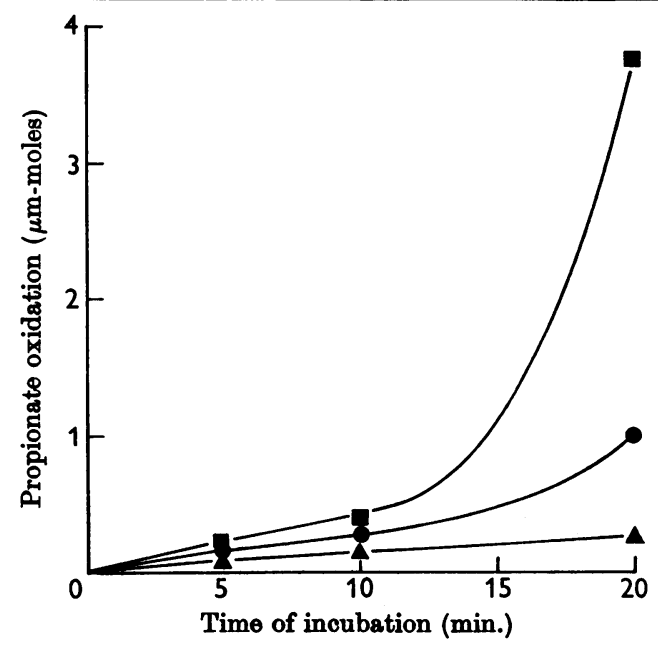

Fig. 3. Effect of cyanocobalamin and dimethylbenzimidazolylcobamide coenzyme on the oxidation of $\left[2-{ }^{14} \mathrm{C}\right]$ propionate. Each Warburg flask (see Experimental section) contained $1.6 \times 10^{8}$ cells with no addition $(\Delta)$, with $1 \mu \mathrm{g}$. of cyanocobalamin (O) or with $1 \mu \mathrm{g}$. of dimethylbenzimidazolylcobamide coenzyme $(\square)$.

Table 4. Oxidation of propionate in the presence of dimethylbenzimidazolylcobamide coenzyme and effect of the methylamide and anilide analogues of cyanocobalamin

Each Warburg flask contained $1.7 \times 10^{8}$ cells and sodium [2.14 C]propionate $(0.68 \mu \mathrm{C}, 0.44 \mu$ mole) in water (2 ml.). Incubation was for $1 \mathrm{hr}$. at $30^{\circ}$ in the dark. DMBC, Dimethylbenzimidazolylcobamide.

\begin{tabular}{|c|c|c|c|}
\hline Compound added & $\begin{array}{l}\text { Concn. } \\
(\mu \mathrm{g} \cdot / \mathrm{ml} .)\end{array}$ & $\begin{array}{c}\text { Sp. activity } \\
\text { of } \mathrm{BaCO}_{3} \\
(\mu \mathrm{c} / \mathrm{g} .)\end{array}$ & $\begin{array}{l}\text { Propionate } \\
\text { oxidized } \\
\text { ( } \mu \mathrm{m}-\mathrm{moles})\end{array}$ \\
\hline None & - & $0.047,0.049$ & $1 \cdot 55,1 \cdot 6$ \\
\hline $\begin{array}{l}\text { Cyanocobalamin } \\
\text { DMBC coenzyme }\end{array}$ & $\begin{array}{l}0.01 \\
0.01\end{array}$ & $\begin{array}{l}0.136,0 \cdot 139 \\
0.278,0.255\end{array}$ & $\begin{array}{l}4 \cdot 4,4 \cdot 5 \\
9 \cdot 0,8 \cdot 3\end{array}$ \\
\hline Cyanocobalamin & 0.01 & .210, 0.200 & 80,00 \\
\hline Anilide & $10\}$ & $0.059,0.061$ & $1 \cdot 9,2 \cdot 0$ \\
\hline $\begin{array}{l}\text { Cyanocobalamin } \\
\text { Methylamide }\end{array}$ & $\left.\begin{array}{c}0 \cdot 01 \\
10\end{array}\right\}$ & $0.770,0.722$ & $24 \cdot 9,23 \cdot 3$ \\
\hline $\begin{array}{l}\text { DMBC coenzyme } \\
\text { Anilide }\end{array}$ & $\left.\begin{array}{c}0 \cdot 01 \\
10\end{array}\right\}$ & $0 \cdot 058,0.0545$ & $1 \cdot 9,1 \cdot 7$ \\
\hline $\begin{array}{l}\text { DMBC coenzyme } \\
\text { Methylamide }\end{array}$ & $\left.\begin{array}{c}0.01 \\
10\end{array}\right\}$ & $0.731,0.648$ & $23 \cdot 6,20 \cdot 9$ \\
\hline Cyanocobalamin* & 0.01 & $0.002,0.003$ & $0.06,0.06$ \\
\hline
\end{tabular}

* Control flasks kept at $0^{\circ}$. 
Table 5. Stimulation of propionate oxidation by different concentrations of cyanocobalamin and its methylamide analogue

Each flask contained $1.56 \times 10^{8}$ cells and sodium [2-14 $\left.\mathrm{C}\right]$ propionate $(0.62 \mu \mathrm{c}, 0.585 \mu \mathrm{mole})$ in water $(2 \mathrm{ml}$.$) .$ Incubation was for $1 \mathrm{hr}$. at $30^{\circ}$.

\begin{tabular}{|c|c|c|c|}
\hline Compound added & $\begin{array}{l}\text { Concn. } \\
(\mu \mathrm{g} / \mathrm{ml} .)\end{array}$ & $\begin{array}{c}\text { Sp. activity } \\
\text { of } \mathrm{BaCO}_{3} \\
(\mu \mathrm{c} / \mathrm{g} .)\end{array}$ & $\begin{array}{l}\text { Propionate } \\
\text { oxidized } \\
\text { ( } \mu \mathrm{m}-\mathrm{moles})\end{array}$ \\
\hline Cyanocobalamin & $\begin{array}{c}0 \cdot 01 \\
0 \cdot 10 \\
1 \cdot 0 \\
10 \cdot 0\end{array}$ & $\begin{array}{l}0 \cdot 116,0 \cdot 106 \\
0 \cdot 849,0 \cdot 925 \\
1 \cdot 49,1 \cdot 58 \\
1 \cdot 64,1 \cdot 56\end{array}$ & $\begin{array}{c}5 \cdot 4,4 \cdot 9 \\
43 \cdot 6,47 \cdot 5 \\
77 \cdot 1,81 \cdot 5 \\
84 \cdot 6,80 \cdot 6\end{array}$ \\
\hline $\begin{array}{l}\text { Methylamide analogue of } \\
\text { cyanocobalamin }\end{array}$ & $\begin{array}{r}0 \cdot 1 \\
1 \cdot 0 \\
10 \cdot 0\end{array}$ & $\begin{array}{l}0 \cdot 347,0 \cdot 366 \\
0 \cdot 377,0 \cdot 377 \\
0 \cdot 404,0 \cdot 408\end{array}$ & $\begin{array}{l}17 \cdot 4,18 \cdot 4 \\
19 \cdot 0,19 \cdot 0 \\
20 \cdot 4,20 \cdot 6\end{array}$ \\
\hline None & - & $0.038,0.033$ & $1 \cdot 4,1 \cdot 1$ \\
\hline Cyanocobalamin* & $10 \cdot 0$ & $0.013,0.010$ & $0.5,0.3$ \\
\hline
\end{tabular}

* Control flasks kept at $0^{\circ}$.

Table 6. Effect of the methylamide analogue of cyanocobalamin on growth and on oxidation of sodium $\left[2-{ }^{14} \mathrm{C}\right]$ propionate by cultures of Ochromonas malhamensis

Each bottle contained $2 \times 10^{8}$ cells in growth medium (100 ml.). Shaking was maintained at $30^{\circ}$ in the dark for $24 \mathrm{hr}$. Cell density was then measured and sodium $\left[2-{ }^{14} \mathrm{C}\right]-$ propionate $(0.5 \mu \mathrm{C}, 10.3 \mu \mathrm{moles})$ was introduced. Shaking was continued for a further $2 \mathrm{hr}$. The period at $0^{\circ}$, after the injection of $10 \%$ trichloroacetic acid (see Experimental section) was extended overnight.

\begin{tabular}{cccc}
$\begin{array}{c}\text { Cyanoco- } \\
\text { balamin } \\
(\mu \mathrm{mg} . / \mathrm{ml} .)\end{array}$ & $\begin{array}{c}\text { Methyl- } \\
\text { amide } \\
(\mu \mathrm{mg} / \mathrm{ml})\end{array}$ & $\begin{array}{c}10^{6} \times \text { Cells } / \mathrm{ml} . \\
\text { after } 24 \mathrm{hr} .\end{array}$ & $\begin{array}{c}\text { oxidized } \\
\text { in } 2 \mathrm{hr} . \\
\left(\mu \mathrm{moles} / 10^{6}\right. \\
\text { cells })\end{array}$ \\
\hline- & - & 2.6 & $0 \cdot 10$ \\
0.02 & - & 3.6 & 0.12 \\
0.05 & - & 5.5 & 0.09 \\
0.20 & - & 7.4 & 0.17 \\
50.00 & - & 7.0 & 10.80 \\
0.05 & 50 & 4.0 & $7 \cdot 43$ \\
0.05 & 500 & 2.8 & 5.90 \\
\hline
\end{tabular}

low concentrations (Table 5). Thus at $0 \cdot 1 \mu \mathrm{g} . / \mathrm{ml}$. the methylamide had almost $40 \%$ of the activity of cyanocobalamin, although at higher concentrations it was relatively less effective.

This vitamin $B_{12}$-like activity of the methylamide analogue could also be demonstrated under conditions of actual growth inhibition after prolonged incubation of cells in growth medium in the presence of the antagonist (Table 6). That oxidation of $\left[2-{ }^{14} \mathrm{C}\right]$ propionate in the presence of the methylamide involves the methylmalonate-succinate pathway is shown by the increase in the radioactivity of succinate when either the analogue or cyanocobalamin was added (Table 3). Moreover the effect of the methylamide on the labelling of succinate is quantitatively similar to that on the conversion of propionate into $\mathrm{CO}_{2}$.
The effect of several other compounds related to cyanocobalamin on the oxidation of propionate is compared in Table 7. Apart from cyanocobalamin itself and the closely related benzimidazolylcobamide, the methylamide is one of the most active compounds. Its activity is similar to that of dichlorobenzimidazolylcobamide and greater than that of 5-hydroxybenzimidazolylcobamide (vitamin $\left.B_{12 \mathrm{nII}}\right)$. In Table 8, the growth-promoting activities of those compounds that stimulated propionate oxidation have been compared. Correlation between activity for growth and propionate oxidation is by no means complete. In particular vitamin $B_{12 \mathrm{III}}$ stimulates growth but has little effect on propionate oxidation; the methylamide analogue inhibits growth but increases propionate oxidation markedly. Secondly, both the methylamide analogue and 5,6-dichlorobenzimidazolylcobamide stimulate propionate oxidation to the same extent, but only the latter compound supports growth.

\section{DISCUSSION}

In earlier work on the function of vitamin $B_{12}$ in the metabolism of Ochromonas malhamensis, several effects of the vitamin were observed. Thus in the absence of the vitamin there is a decrease in protein synthesis which is apparently due to the decreased ability of deficient cells to synthesize certain amino acids, notably valine, phenylalanine and tyrosine (Arnstein \& White, 1959, $1961 b$ ). There is, however, no complete block in any of these metabolic pathways, and addition of vitamin $B_{12}$ gives at best only a fivefold increase in the biosynthesis of these amino acids. Similar investigations of the one-carbon-atom metabolism of Ochromonas showed that the stimulation of methyl group biosynthesis by vitamin $\mathrm{B}_{12}$ was also relatively small and not specific (White \& Arnstein, 


\section{Table 7. Effect of vitamin $B_{12}$ analogues on the oxidation of propionate}

Each Warburg flask contained $1.8 \times 10^{8}$ cells and sodium $[2.14 \mathrm{C}]$ propionate $(0.50 \mu 0,0.62 \mu$ mole in Expt. no. 3; $0.64 \mu \mathrm{c}, 0.81 \mu$ mole in Expt. no. 4) in water (2 ml.). The compounds were added to a concentration of $1 \mu \mathrm{g} . / \mathrm{ml}$., except where otherwise stated. Incubation was at $30^{\circ}$ for $2 \mathrm{hr}$.

Expt.
no.
$\mathbf{3}$
$\mathbf{3}$
$\mathbf{3}$
$\mathbf{3}$
$\mathbf{3}$
$\mathbf{3}$
$\mathbf{3}$
$\mathbf{3}$
$\mathbf{3}$
$\mathbf{3}$
$\mathbf{4}$
$\mathbf{4}$
$\mathbf{4}$
$\mathbf{4}$
$\mathbf{4}$
$\mathbf{4}$
$\mathbf{3}$
$\mathbf{4}$

Compound added
Cyanocobalamin
Methylamide analogue of
cyanocobalamin
Benzimidazolylcobamide
Dichlorobenzimidazolylcobamide
5-Hydroxybenzimidazolylcobamide
2-Methyladenylcobamide
Adenylcobamide
Cobinamide
2-Methylmercapto-6-hydroxy-
purinylcobamide
None
Cyanocobalamin
Methylamide analogue of
cyanocobalamin (0.1 $\mu$ g./ml.)
Benzimidazolylcobamide
Dichlorobenzimidazolylcobamide
5-Hydroxybenzimidazolylcobamide
None
Cyanocobalamin Control flasks
Cyanocobalamin

\begin{tabular}{|c|}
\hline $\begin{array}{l}\text { Sp. activity } \\
\text { of } \mathrm{BaCO}_{3} \\
(\mu \mathrm{c} / \mathrm{g} .)\end{array}$ \\
\hline $\begin{array}{l}4 \cdot 51,4 \cdot 87 \\
0 \cdot 886,0 \cdot 954\end{array}$ \\
\hline $\begin{array}{l}2.26 \\
0.524,0.726 \\
0.175,0.164 \\
0.065,0.083 \\
0.060,0.059 \\
0.057,0.055 \\
0.068,0.058\end{array}$ \\
\hline $\begin{array}{l}0 \cdot 080,0 \cdot 065 \\
6 \cdot 87,6 \cdot 81 \\
1 \cdot 28,1 \cdot 16\end{array}$ \\
\hline $\begin{array}{l}3 \cdot 60,3 \cdot 89 \\
1 \cdot 54 \\
0 \cdot 331,0 \cdot 366 \\
0.087,0 \cdot 086\end{array}$ \\
\hline $\begin{array}{l}0.003 \\
0.005\end{array}$ \\
\hline
\end{tabular}

$\begin{gathered}\text { Propionate } \\ \text { oxidized } \\ (\mu \mathrm{m}-\text { moles })\end{gathered}$
280,302
$54 \cdot 9,59 \cdot 1$

138
$32 \cdot 5,45 \cdot 0$
$10 \cdot 9,10 \cdot 2$
$4 \cdot 0,5 \cdot 1$
$3 \cdot 7,3 \cdot 7$
$3 \cdot 6,3 \cdot 4$
$4 \cdot 2,3 \cdot 6$
$5 \cdot 0,4 \cdot 1$
478,472
$89 \cdot 1,80 \cdot 1$

249,269
108
$22 \cdot 6,25 \cdot 0$
$5 \cdot 7,5 \cdot 6$
$0 \cdot 24$
$0 \cdot 37$

Table 8. Comparison of effects of compounds related to cyanocobalamin on the growth of Ochromonas malhamensis and on the oxidation of propionate by this organism

Activity of the compounds for propionate oxidation has been calculated from the average results in Table 7; that for growth is taken from the review by Coates \& Kon (1957).

Compound
Cyanocobalamin
Benzimidazolylcobamide
Methylamide analogue of cyanocobalamin
5,6-Dichlorobenzimidazolylcobamide
5-Hydroxybenzimidazolylcobamide

$\begin{array}{cc}\begin{array}{c}\text { Activity for } \\ \text { propionate }\end{array} & \\ \text { oxidation } & \text { Growth } \\ 100 & 100 \\ 51 & 40 \\ 19 & \text { Inhibition } \\ 18 & >100 \\ 4 & 50\end{array}$

1961; White, 1961). From this work it was concluded that, in this organism, unlike in Escherichia coli (Guest \& Woods, 1960; Takeyama, Hatch \& Buchanan, 1961), vitamin $B_{12}$ is not directly involved in the biosynthesis of methionine or of other methyl groups.

We have now found that vitamin $B_{12}$-deficient cells are unable to oxidize propionate, although their ability to oxidize glucose, acetate and formate is affected only to a small extent or not at all. Moreover, addition of vitamin $B_{12}$ results in a rapid and marked increase (up to over 100-fold) in the rate of propionate oxidation. A major effect of vitamin $B_{12}$ on the metabolism of propionate by $O$. malhamensis has also been found recently by Marchesi \& Lajtha (1961). The metabolism of propionate by this organism appears to involve methylmalonate and succinate as intermediates, as shown by the conversion of labelled propionate into these compounds. In the absence of vitamin $B_{12}$ only methylmalonate becomes labelled and the vitamin thus functions in the isomerization of methylmalonate to succinate. It has already been demonstrated with cell-free preparations from other species, including Propionibacterium (Stadtman, Overath, Eggerer \& Lynen, 1960) and rat liver (Gurnani, Mistry \& Johnson, 1960) or sheep kidney (Lengyel, Mazumder \& Ochoa, 1960), that the coenzyme form of vitamin $B_{12}$, dimethylbenzimidazolylcobamide (Weissbach et al. 1959), is required as a cofactor in this reaction.

In vitamin $B_{12}$-deficient sheep, it is considered that the disturbance of normal propionate metabolism adequately explains the observed effects of the deficiency (Marston, Shirley \& Smith, 1961). The question arises, however, whether this metabolic function accounts also for the growthpromoting activity of vitamin $B_{12}$ in animals other 
than ruminants and in many micro-organisms, as well as for its effects on erythropoiesis and brain metabolism in human pernicious anaemia.

The present work shows that the effect of vitamin $B_{12}$ on propionate metabolism, although quantitatively very marked, appears to be unrelated to the stimulation of growth, since there was no correlation between these activities in several compounds related to cyanocobalamin (see Table 8). It is concluded therefore that, in addition to its function in the isomerization of methylmalonate and succinate, vitamin $B_{12}$ is involved in another metabolic pathway which is evidently of greater importance for growth of this organism and possibly also of animals. This pathway is still unknown and it remains to be investigated whether it can be identified with one for which, in other organisms, vitamin $B_{12}$ is known to be required, e.g. deoxyriboside synthesis in lactobacilli (Spell \& Dinning, 1959; Manson, 1960) or the isomerization of propanediol to propionaldehyde in Aerobacter aerogenes (Brownstein \& Abeles, 1961), or whether there exists an entirely new vitamin $B_{12}$-dependent reaction.

\section{SUMMARY}

1. The effect of vitamin $B_{12}$ on the oxidation of $\left[{ }^{14} \mathrm{C}\right]$ glucose, $\left[{ }^{14} \mathrm{C}\right]$ formate, $\left[{ }^{14} \mathrm{C}\right]$ acetate and $\left[{ }^{14} \mathrm{C}\right]$ propionate by vitamin $B_{12}$-deficient cell suspensions of Ochromonas malhamensis has been studied.

2. The oxidation of glucose, formate and acetate is affected little or not at all, but in the absence of vitamin $B_{12}$ there is a virtually complete block in the oxidation of propionate.

3. Addition of cyanocobalamin rapidly stimulates propionate oxidation to a very marked extent.

4. Several analogues of cyanocobalamin have been tested for their effect on propionate oxidation and their activity has been compared with their ability to promote growth.

5. Whereas most compounds were either inactive or active in both tests, the methylamide analogue stimulated propionate oxidation but inhibited growth and 5-hydroxybenzimidazolylcobamide (vitamin $\mathbf{B}_{12 \mathrm{III}}$ ) stimulated growth but increased propionate oxidation only slightly.

6. It is concluded that, in addition to its function in the propionate-methylmalonate-succinate pathway, vitamin $B_{12}$ is involved in another reaction which is important for the growth of this organism and possibly of animals also.
We thank Mrs B. Higginson and Mr E. J. Toms for technical assistance, Dr J. E. Ford for supplying the organism and some of the vitamin $B_{12}$ analogues and for advice about media, and Dr E. Lester Smith, F.R.S., for gifts of the vitamin $B_{12}$ antagonists.

\section{REFERENCES}

Arnstein, H. R. V. \& White, A. M. (1959). Biochim. biophys. Acta, 36, 286.

Arnstein, H. R. V. \& White, A. M. (1961a). Biochem. J. 79, 3P.

Arnstein, H. R. V. \& White, A. M. (1961b). In Second European Symposium on Vitamin $B_{12}$ and Intrinsic Factor, Hamburg (in the Press).

Brownstein, A. M. \& Abeles, R. H. (1961). J. biol. Chem. 236, 1199.

Coates, M. E. \& Ford, J. E. (1955). Symp. biochem. Soc. no. $13,36$.

Coates, M. E. \& Kon, S. K. (1957). In Vitamin $B_{12}$ und Intrinsic Factor, p. 72. Ed. by Heinrich, H. C. Stuttgart: Ferdinand Enke Verlag.

Ford, J. E. (1953). Brit. J. Nutr. 7, 299.

Ford, J. E. (1959). J. gen. Microbiol. 21, 693.

Guest, J. R. \& Woods, D. D. (1960). Biochem. J. 77, 422.

Gurnani, S., Mistry, S. P. \& Johnson, B. C. (1960). Biochim. biophys. Acta, 38, 187.

Hutner, S. H., Provasoli, L. \& Filfus, J. (1953). Ann. N.Y. Acad. Sci. 56, 852.

Johnson, B. C., Holdsworth, E. S., Porter, J. W. G. \& Kon, S. K. (1957). Brit. J. Nutr. 11, 313.

Lengyel, P., Mazumder, R. \& Ochoa, S. (1960). Proc. nat. Acad. Sci., Wash., 46, 1312.

Manson, L. A. (1960). J. biol. Chem. 235, 2955.

Marchesi, S. L. \& Lajtha, L. G. (1961). In Second European Symposium on Vitamin $B_{12}$ and Intrinsic Factor, Hamburg (in the Press).

Marston, H. R., Shirley, H. A. \& Smith, R. M. (1961). Nature, Lond., 190, 1085.

Popják, G. (1950). Biochem. J. 46, 560.

Spell, W. H., jun. \& Dinning, J. S. (1959). J. Amer. chem. Soc. 81, 3804.

Stadtman, E. R., Overath, P., Eggerer, H. \& Lynen, F. (1960). Biochim. biophys. Res. Comm. $2,1$.

Swim, H. E. \& Krampitz, L. O. (1954). J. Bact. 67, 419.

Takeyama, S., Hatch, F. T. \& Buchanan, J. M. (1961). J. biol. Chem. 236, 1102.

Weissbach, H., Toohey, J. \& Barker, H. A. (1959). Proc. nat. Acad. Sci., Wash., 45, 521.

White, A. M. (1961). Abstr. Comm. 5th int. Congr. Biochem., $M o s c o w$, no. 14/132, p. 301.

White, A. M. \& Arnstein, H. R. V. (1960). Biochem. J. 78, $10 \mathrm{P}$.

White, A. M. \& Arnstein, H. R. V. (1961). In Second European Symposium on Vitamin $B_{12}$ and Intrinsic Factor, Hamburg (in the Press). 